\title{
Life Cycle Assessment of Disposed and Recycled End-of-Life Photovoltaic Panels in Australia
}

\author{
Jasleen Kaur Daljit Singh ${ }^{1}$, Georgina Molinari ${ }^{1}$, Jonathan Bui ${ }^{1}$, Behdad Soltani ${ }^{1,2}{ }^{1}$, \\ Gobinath Pillai Rajarathnam ${ }^{1,2(1)}$ and Ali Abbas ${ }^{1, *(1)}$
}

1 School of Chemical and Biomolecular Engineering, The University of Sydney, Sydney, NSW 2006, Australia; jasleen.daljitsingh@sydney.edu.au (J.K.D.S.); gmol5380@uni.sydney.edu.au (G.M.); jbui6800@uni.sydney.edu.au (J.B.); behdad.soltani@sydney.edu.au (B.S.); gobinath.rajarathnam@sydney.edu.au (G.P.R.)

2 Mercularis Pty. Ltd., Sydney, NSW 2145, Australia

* Correspondence: ali.abbas@sydney.edu.au; Tel.: +61-(2)-9351-3002

Citation: Daljit Singh, J.K.;

Molinari, G.; Bui, J.; Soltani, B.;

Rajarathnam, G.P.; Abbas, A. Life

Cycle Assessment of Disposed and Recycled End-of-Life Photovoltaic Panels in Australia. Sustainability 2021, 13, 11025. https://doi.org/ $10.3390 /$ su131911025

Academic Editor: Domenico Mazzeo

Received: 28 August 2021

Accepted: 27 September 2021

Published: 5 October 2021

Publisher's Note: MDPI stays neutral with regard to jurisdictional claims in published maps and institutional affiliations.

Copyright: (c) 2021 by the authors. Licensee MDPI, Basel, Switzerland. This article is an open access article distributed under the terms and conditions of the Creative Commons Attribution (CC BY) license (https:// creativecommons.org/licenses/by/ $4.0 /)$.

\begin{abstract}
This study presents a life cycle assessment (LCA) of end-of-life (EoL) photovoltaic (PV) systems in Australia. Three different EoL scenarios are considered for $1 \mathrm{kWh}$ of electricity generation across a 30-year PV system lifespan: (i) disposal to landfill, (ii) recycling by laminated glass recycling facility (LGRF), and (iii) recycling by full recovery of EoL photovoltaics (FRELP). It is found that recycling technologies reduce the overall impact score of the cradle-to-grave PV systems from 0.00706 to 0.00657 (for LGRF) and 0.00523 (for FRELP), as measured using the LCA ReCiPe endpoint single score. The $\mathrm{CO}_{2}$ emissions to air decrease slightly from $0.059 \mathrm{~kg} \mathrm{CO}_{2}$ per $\mathrm{kWh}$ (landfill) to $0.054 \mathrm{~kg}$ $\mathrm{CO}_{2}$ per $\mathrm{kWh}$ (for LGRF) and $0.046 \mathrm{~kg} \mathrm{CO} 2$ per $\mathrm{kWh}$ (for FRELP). Increasing the PV system lifespan from 30 years to 50 and 100 years (a hypothetical scenario) improves the ReCiPe endpoint singlescore impact from 0.00706 to 0.00424 and 0.00212 , respectively, with corresponding $\mathrm{CO}_{2}$ emissions reductions from $0.059 \mathrm{~kg} \mathrm{CO} 2$ per $\mathrm{kWh}$ to 0.035 and $0.018 \mathrm{~kg} \mathrm{CO}$ per $\mathrm{kWh}$, respectively. These results show that employing recycling slightly reduces the environmental impact of the EoL PV systems. It is, however, noted that recycling scenarios do not consider the recycling plant construction step due to a lack of data on these emerging PV panel recycling plants. Accounting for the latter will increase the environmental impact of the recycling scenarios, possibly defeating the purpose of recycling. Increasing the lifespan of the PV systems increases the longevity of the use of panel materials and is therefore favorable towards reducing environmental impacts. Our findings strongly suggest that PV recycling steps and technologies be carefully considered before implementation. More significantly, it is imperative to consider the circular design step up front, where PV systems are designed via circular economy principles such as utility and longevity and are rolled out through circular business models.
\end{abstract}

Keywords: circular economy; LCA; photovoltaic panels; recycling; circular design; carbon emissions

\section{Introduction}

The use of renewable energy has grown significantly over recent decades, gradually reducing the global dependence on fossil fuels [1]. Of these renewables, solar photovoltaic (PV) technology is said to have the most potential for large scale clean energy generation [2,3], as the modularity of PV panels allows for installation at different scales depending on energy requirements [4]. PV technology produces electricity without producing any noise or air pollution during its operation, making it a popular choice for renewable electricity production [5-7]. The technology around the PV system has also been growing with development of instrumentations such as dual axis solar trackers [8] and low cost PV emulators [9]. This has resulted in the rapid growth of the industry: PV technology grew by $32 \%$ in 2017 , with over 400 GW of PV capacity globally. This capacity is expected to rise exponentially to 4500 GW by 2050 [10]. 
In Australia, the Clean Energy Regulator estimates that over 2.38 million PV systems have been installed with a total rooftop capacity of 10.7 GW as of March 2020 [11]. In the first quarter of 2020 alone, more than 56,000 rooftop installations were registered, which corresponds to approximately $408 \mathrm{MW}$ of capacity up from 48,500 installations and $323 \mathrm{MW}$ in the same quarter of 2019 [11]. These numbers represent the growing trend in Australia regarding solar panel installation, which has a six-month average added capacity of 215 MW between 2012 and 2020. This amounts to approximately $21 \%$ of households nationwide with rooftop PVs. In August 2021, solar power momentarily outstripped energy generation from coal for the first time since the national electricity market began operation in the late 1990s.

With the transition away from fossil fuels accelerating as the world moves through the 21st century, 'green technology' such as PV cells plays a vital role in a low carbon future dominated by a mix of renewable energy generation technologies $[12,13]$. However, the growth of PV technology brings about a new challenge of end-of-life (EoL) management of PV panels. The average lifespan of a crystalline Silicon (c-Si) PV panel is 25 to 30 years [14,15]. After this period, the panels are decommissioned. PV waste is currently considered electronic waste (e-waste), and usually, this e-waste ends up in the landfill or is incinerated, releasing toxic and carcinogenic materials into the air [16].

By 2050, the global PV waste is expected to be approximately $10 \%$ of all Waste Electrical and Electronic Equipment (WEEE) generation $[17,18]$. In Australia alone, it is estimated that the cumulative PV waste by 2047 will be over 800,000 tonnes [14]. The large amount of $\mathrm{PV}$ waste generated could result in unfavorable environmental outcomes if proper EoL management is not implemented. Thought-out EoL management, which encompasses all levels of PV technology, including design, production, operation, and decommissioning, is vital to allow for the development of a circular economy (CE) that seeks to reduce the overall negative impact of technologies.

The circular economy is an economic model regenerative by design that aims to gradually decouple growth from the consumption of finite resources [19]. The circular economy model has a cradle-to-cradle lifecycle that starts with a design process and ends with recycling and the creation of new products, prolonging the lifespan of the original raw materials.

An ideal sustainability goal for the PV industry is to create a robust circular economy. In doing so, energy and material inputs can be reduced throughout the product's entire lifecycle, meaning that the overall environmental impact can be significantly reduced. The PV system design plays a critical role by creating the product that compliments the circular economy framework. In line with circular economy principles, many PV technology researcher teams are switching attention to design and material selection focusing on EoL management of PV technologies.

Several studies have been conducted on the life cycle assessment (LCA) of different EoL frameworks of the PV technology to analyse their impact. However, current LCA studies for PV technologies are limited in that they either (i) focus only on upstream and operational processes such as material extraction and manufacture and create a "black box" surrounding recycling, omitting key details and methods; or (ii) focus entirely on recycling and not emissions from original manufacture. For cradle-to-grave assessments of PV panels, only landfill has been considered. LCAs on PV technology in the Australian context is also lacking.

In this study, we extend upon previous LCA studies on PV systems, while maintaining a focus on circular economy frameworks. In this work, Australia is taken as a case study, and the LCA is conducted on multi-Si solar panels as they are the most widely used in Australia using ReCiPe midpoint and endpoint indicators. The LCA is conducted on three EoL scenarios: landfill, Full Recycling EoL Procedure (FRELP), and Laminated Glass Recyling Facility (LGRF). The novelty of this study is that it considers the impact of the PV panel and considers the impact of the whole PV system, which also includes the environmental impact of the mounting system, the inverter, and the electrical installation, 
in producing $1 \mathrm{kWh}$ of electricity. We also conduct LCA for system lifespans from 30 years to 50 and 100 years (hypothetical scenario). Additionally, in line with LCA standards, this study is a complete cradle-to-grave analysis of the PV system because it considers the production and manufacturing of the panels, the mounting system, the inverter, and the electrical installation. We provide some background on the current PV system in Section 2, including the different types of PV panels and the current EoL practices. We then present a detailed methodology of the LCA study in Section 3. In Section 4, we present the LCA results for the different EoL scenarios, followed by the LCA results for different system lifespans. The discussion and conclusion are presented in Sections 5 and 6, respectively.

\section{Background on PV Systems}

\subsection{Types of Photovoltaic Panels}

PV solar panels can be grouped into three major groups: Silicon-based, thin-film based, and third-generation panels [1]. Thin-film cells include Copper indium gallium (di) selenide (CIGS) and cadmium telluride (CdTe) panels, whilst the "third-generation" category primarily encompasses emerging technology such as perovskite cells, CIGS alternatives, and concentrating PV cells. Currently, silicon cells comprise the majority of worldwide installations, accounting for approximately $85 \%$ of energy output [20].

Silicon-based cells are utilized as the easiest, cheapest, and most efficient cells to be readily produced [21]. Additionally, they are highly recyclable due to the material composition being primarily aluminum, glass, silicon, plastic, and small amounts of other metals such as silver, tin, and lead [22].

The silicon-based cells can be further split into two types, mono- and multi-Si cells. These are both types of crystalline silicon cells that have different arrangements in construction. Mono-Si cells are based on one large crystal, whilst the multi-Si cells are constructed from several separate silicon crystals. In 2016, multi-Si panels had a 55\% market share of technology, whilst mono-Si had 45\% [1].

\subsection{EoL (EoL) Practices}

The EoL treatment of solar panels can occur primarily through two main pathways: either by disposal to landfill or by recycling the panels to recover the component materials and then reusing the components for future solar panel manufacture or other products [10]. The material components are all highly recyclable in silicon cells, with an approximate recovery of $96 \%$ for silicon, glass, aluminum, and other metal components [23].

Manual, chemical, or a mixture of the two methods are used for recycling solar panels (IRENA 2016). However, the global panel recycling industry is small. Most panels are placed into landfill due to the high cost, low research, and lack of developed processes that can be implemented cost-effectively. Despite this, recycling is widely seen, including by associations such as IRENA, as a strong possible EoL option to reduce the number of panels ending up in landfill and recovering material to reduce the need for further mining materials.

There is scarce literature on recycling methods, particularly in modelling and analyzing their impacts on the environment. The merits of the recycling of solar panels as a sustainable EoL solution is unclear, especially considering the energy-intensive and costly nature of current recycling processes. Thus, it is vital to model these recycling processes to quantify their environmental impacts and determine if recycling is a sustainable approach for PV panels.

\subsubsection{Landfill}

Landfill is a commonly used practice in Australia and globally due to the simplicity of the process. This is highlighted by the fact that there is no dedicated large-scale PV recycling plant operating in Australia. This EoL method involves the transportation of the panel from the place of operation to the landfill location. After transport, the panel is simply disposed into the landfill location in one piece, normally reducing possible leeching and 
preventing toxic substances from penetrating the soil from broken pieces. However, this is not always the case in practice as panels break during transport or when they are disposed.

\subsubsection{Full Recycling EoL Procedure (FRELP) Recycling}

The Full Recycling EoL Procedure (FRELP) is a process that has developed from EU research into recycling procedures as a result of the WEEE Directive, which is an extended-producer-responsibility principle setting out the framework in which the producers are legally liable for the costs of collection, transport, treatment, management, and monitoring [24,25].

The development of methodologies regarding collecting and recycling materials has been committed to by the European Commission [25]. The commitment mainly focuses on the research and development of harmful and toxic processes, as well as energy intensive processes.

The WEEE Directive sets out specific targets regarding collection, recovery, and recycling [26]. From 2018, annual collection targets of $85 \%$ of all waste generated and $65 \%$ of all equipment on the market (by mass) have been established [24]. The $65 \%$ target, however, is considered to be unrealistic due to the long lifespan of PV panels [1]. Additionally, 85\% of materials should be recovered, while $80 \%$ should be reused or recycled [24].

The FRELP procedure was developed to meet recovery targets. This process combines chemical and mechanical processes to separate each material and recover most of the panel. It includes processes such as the disassembly of frame ad cables (incineration of cables), glass separation and refinement, cutting off cells and incineration, sieving of fly ash from incineration, acid leaching, filtration, electrolysis, neutralization, and filter pressing [22].

In recent years, the FRELP recycling process has been optimized for further recovery with a few modifications. Following acid leaching, sequential electrowinning occurs to produce SiNx going to chemical etching followed by sheet resistance monitoring [14]. The process then reverts to the basic FRELP process, which is neutralization and then the filter press.

\subsubsection{LGRF Process}

Laminated glass recycling facility processing can occur in other current recycling plants [27] as compared to FRELP, which requires a specific PV recycling plant. However, this type of recycling requires small batches of PV waste rather than a constant stream of PV waste. The LGRF process does not require any additional investment in recycling because the units and equipment required should already be in the recycling plant, and the recovery of materials is limited. Only the recovery of the glass, copper from the cables, and the aluminum frame can occur. The silicon, silver, and other metals in the PV sandwich cannot be recovered and are put into landfill. This reduces the material recovery and increases the risks associated with leaching toxic substances in landfill into soil and possibly water basins.

\subsection{Current EoL Lifecycle Studies}

There has only been one significant study into the impacts of the recycling process, which had otherwise been a "black box". Latunussa et al. [22] was one of the first detailed studies of the recycling process using FRELP where all steps were noted and explained. However, the LCA was only of the recycling procedure, not the entire life cycle.

There is a lack of modelling in the Australian context. Mahmoudi et al. [14] was the first significant LCA study of the recycling process in the Australian context, which was based on the study by Latunussa et al. [22]. Unlike the primary study, Mahmoudi and coworkers included downstream processes such as mining and the manufacturing of the panels.

However, both these LCAs examined the impacts of recycling on a mass basis. One of the significant advantages of LCAs is that they can be used for direct comparison between different technologies. Most LCAs use a functional unit of energy for direct comparisons in 
energy production, such as $1 \mathrm{kWh}$ or MWh. These prior studies do not do this, limiting their potential conclusions and comparisons.

\section{Methodology}

A life cycle assessment (LCA) was performed for the EoL of solar photovoltaic systems in Australia according to the globally established standards, ISO 14040 and ISO $14044[28,29]$. The LCA study was conducted in four steps: (1) goal and scope definition, (2) life cycle inventory collection, (3) life cycle impact assessment, and (4) result interpretation.

\subsection{Life Cycle Assessment: Goal and Scope}

This study aims to assess the environmental impacts associated with the EoL disposal of PV systems in Australia. A cradle-to-grave approach is taken, where the production of the PV system, electricity generation, and the disposal of the PV system at the end of its life are considered. The environmental impact caused by the sub-assemblies of the PV system is evaluated. The four sub-assemblies are the PV panel, the mounting system, the inverter, and the electrical installation system. For the mounting system, the inverter, and the electrical installation system, only disposal to the landfill is considered. For the disposal of the PV panel, three EoL options are considered: disposal into a landfill, FRELP (Full Recovery EoL Photovoltaic), and LGRF (Laminated Glass Recycling Facility) are considered.

The transmission of electricity across the grid is not considered in all cases as it is not in the scope of this study. The construction of recycling facilities is also not considered, as we do not have the required data. A functional unit (FU) of $1 \mathrm{kWh}$ will allow for comparison between the different scenarios tested. The system boundary is given in Figure 1. The PV panel assessed in this study is a multi-silicon panel as it is the most commonly installed PV technology globally at $62 \%$ market share in 2017 [20].

For all the above EoL scenarios, the LCA was first conducted based on a 30-year lifespan of panels. Then, an alternative approach was evaluated for the landfill scenario where different panel lifespans were considered: 30 years, 50 years, and 100 years, which were selected arbitrarily.

\subsection{Life Cycle Inventory}

The processes were modelled using OpenLCA (v1.10.3) software by GreenDelta. The Ecoinvent v3.6 database was used within the software for processes and materials required in the development of the lifecycle model. The inventory for the production and installation of PV panels, slanted roof mounting system, inverter, and electrical installation system were obtained from Ecoinvent 3.6. The composition of a PV panel varies slightly depending on the panel's age, manufacturer, and condition. For this study, the compositions of the panels were adapted from Latunussa et al. [22] and are shown in Table 1. 


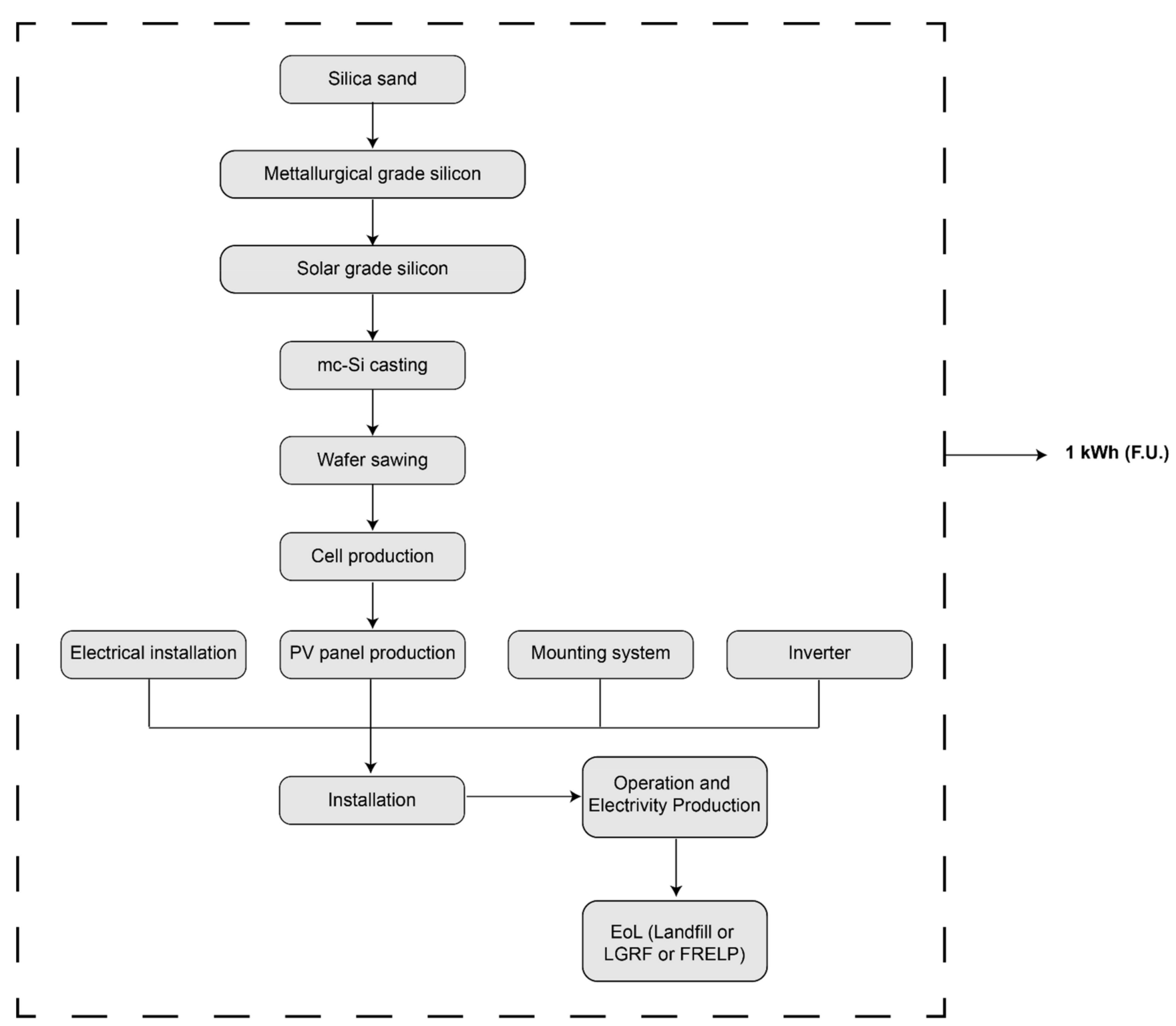

Figure 1. System boundary of the Life Cycle Assessment. The functional unit is $1 \mathrm{kWh}$ electricity generation.

Table 1. Mass composition of PV panels (adapted from Latunussa et. al. 2016).

\begin{tabular}{cc}
\hline Component & Ratio \\
\hline Glass & 0.7 \\
Copper & 0.00461 \\
Aluminum & 0.185 \\
Silicon & 0.0365 \\
Silver & 0.00053 \\
EVA & 0.051 \\
PVF & 0.015 \\
PVC & 0.00683 \\
Tin & 0.000265 \\
Lead & 0.000265 \\
Total & $\mathbf{1}$ \\
\hline
\end{tabular}

Inventories for the recycling processes were obtained from the literature. The LCI for the LGRF recycling process was obtained from a survey done by IEA's Task Force 12 [30]. This survey was conducted for the Maltha laminated glass facility in Belgium. The LCI for 
FRELP was also obtained from previous studies [22,31]. The inventories were adapted for a functional unit of $1 \mathrm{kWh}$. The inventories for the FRELP and LGRF recycling for 1 tonne of PV panel are given in Tables 2 and 3, respectively. For the generation of $1 \mathrm{kWh}$ of electricity, $3.34 \times 10^{-6}$ tonnes of PV panels are needed according to Ecoinvent v3.6, so the inventories were modified to that for the LCA.

Table 2. Life Cycle Inventory for the FRELP recycling process for 1 tonne of PV panel.

\begin{tabular}{ccc}
\hline Inputs & & \\
\hline PV waste panels & 1 & tonne \\
Electricity & 0.11355 & $\mathrm{kWh}$ \\
Diesel fuel & 0.00114 & Liter \\
Water & 0.40971 & tonne \\
$\mathrm{HNO}_{3}$ & 0.00708 & tonne \\
NaOH & 0.00708 & tonne \\
HF & 0.00708 & tonne \\
Ca(OH) 2 & 0.0365 & tonne \\
Aluminum & & \\
Glass & 0.168 & tonne \\
Copper & 0.693 & tonne \\
Solar-grade Si & 0.00438 & tonne \\
Silver & 0.03466 & tonne \\
Lead & 0.0005 & tonne \\
Tin & 0.00025 & tonne \\
Outputs Recovered Materials & 0.00025 & tonne \\
Electricity & & \\
Thermal energy & 0.24884 & $\mathrm{kWh}$ \\
Output, Waste to Landfill & 0.50284 & $\mathrm{MJ}$ \\
Contaminated glass & & \\
Fly ash & 0.014 & tonne \\
Liquid waste & 0.002 & tonne \\
Sludge & 0.40613 & tonne \\
Output, Emission to Air & 0.05025 & tonne \\
NOx & 0.002 & tonne \\
\hline
\end{tabular}

Table 3. Life Cycle Inventory for the LGRF recycling process for 1 tonne of PV panel.

\begin{tabular}{ccc}
\hline Inputs & & \\
\hline PV waste panels & 1 & tonne \\
Glass & 0.7 & tonne \\
Copper & 0.00461 & tonne \\
Aluminum & 0.185 & tonne \\
Silicon & 0.0365 & tonne \\
Silver & 0.00053 & tonne \\
EVA & 0.051 & tonne \\
PVF & 0.015 & tonne \\
PVC & 0.00683 & tonne \\
Tin & 0.000265 & tonne \\
Lead & 0.000265 & tonne \\
Glass & & tonne \\
Copper & 0.644 & tonne \\
Aluminum & 0.0018901 & tonne \\
Outputs, Other & 0.13505 & tonne \\
Incineration & & \\
Landfill & 0.16 & tonne \\
\hline & 0.059 & tonne \\
\hline
\end{tabular}




\subsubsection{Life Cycle Impact Assessment Methodology}

In this LCA, ReCiPe midpoint and endpoint factors were used to assess the environmental impact of the different scenarios [32]. The ReCiPe method consists of 18 midpoint and 3 endpoint indicators. The midpoint indicators considered are ozone depletion, agricultural land occupation, marine eutrophication, human toxicity, climate change potential, terrestrial acidification, freshwater eutrophication, photochemical oxidant formation, ionizing radiation, urban land occupation, particulate matter formation, terrestrial ecotoxicity, freshwater ecotoxicity, marine ecotoxicity, natural land transformation, water depletion, metal depletion, and fossil fuel depletion. An overview of these indicators is given in Table 4. The three endpoint indicators are damage to ecosystem quality, damage to human health, and damage to resources [32]. The sum of these categories is tabulated to obtain a total endpoint score.

Table 4. ReCiPe LCA method (Goedkoop et al. 2013).

\begin{tabular}{ccc}
\hline Mid-Point Impact Category. & Unit & Indicator \\
\hline Climate change (CC) & $\mathrm{kg}\left(\mathrm{CO}_{2}\right.$ to air) & Global warming potential (GWP100) \\
Ozone depletion (OD) & $\mathrm{kg}(\mathrm{CFC}-11$ to air) & Ozone depletion potential (ODP) \\
Terrestrial acidification (TA) & $\mathrm{kg}\left(\mathrm{SO}_{2}\right.$ to air) & Terrestrial acidification potential (TAP100) \\
Freshwater eutrophication (FE) & $\mathrm{kg}$ (P to freshwater) & Freshwater eutrophication potential (FEP) \\
Marine eutrophication (ME) & $\mathrm{kg}$ (N to freshwater) & Marine eutrophication potential (MEP) \\
Human toxicity (HT) & $\mathrm{kg}(14 \mathrm{DCB}$ to urban air) & Human toxicity potential (HTPinf) \\
Potential oxidant formation (POF) & $\mathrm{kg}$ (NMVOC to air) & Photochemical oxidant formation potential (POFP) \\
Particulate matter formation (PMF) & $\mathrm{kg}$ (PM to air) & Particulate matter formation potential (PMPF) \\
Terrestrial ecotoxicity (TET) & $\mathrm{kg}(14 \mathrm{DCB}$ to industrial soil) & Terrestrial ecotoxicity potential (TETinf) \\
Freshwater ecotoxicity (FET) & $\mathrm{kg}(14 \mathrm{DCB}$ to freshwater) & Freshwater ecotoxicity potential (FETPinf) \\
Marine ecotoxicity (MET) & $\mathrm{kg}(14 \mathrm{DCB}$ to marine water) & Marine ecotoxicity potential (METPinf) \\
Ionizing radiation (IR) & $\mathrm{kg}$ (U235 to air) & Ionizing radiation potential (IRP) \\
Agricultural land occupation (ALO) & $\mathrm{M} 2 \times$ year (agricultural land) & Agricultural land occupation potential (ALOP) \\
Urban land occupation (ULO) & $\mathrm{M} 2 \times$ year (urban land) & Urban land occupation potential (ULOP) \\
Water depletion (WD) & $\mathrm{M} 3$ (water) & Water depletion potential (WDP) \\
Metal resource depletion (MRD) & $\mathrm{kg}$ (Fe) & Metal depletion potential (MDP) \\
Fossil resource depletion (FD) & $\mathrm{kg}$ (oil) & Fossil depletion potential (FDP) \\
\hline
\end{tabular}

Three different uncertainty perspectives can be implemented in the ReCiPe method: individualist (I), hierarchist (H), and egalitarian (E) [33]. The individualist perspective is technologically optimistic and takes the short-term into account. The egalitarian perspective takes a precautionary approach and takes the longest time frame into account. The hierarchist perspective is the most widely used, relies on common policy principles, and has a moderate time frame. As such, the hierarchist uncertainty was chosen as it provides a reasonable balance between the short and long time frames.

In the case of an LCA for energy production, most results focus on the GHG emissions, primarily the release of carbon dioxide $\left(\mathrm{CO}_{2}\right)$ per unit of energy generated [34]. Other emissions also occur, which have significant impacts on climate change and the environment, for example, hydrofluorocarbons and methane are also emitted in the energy production process. As such, the main measure of GHG emissions and climate change are the $\mathrm{CO}_{2}$ equivalent emissions per functional unit (for example, $\mathrm{kg} \mathrm{CO}_{2}$-eq/MWh and $\mathrm{g}$ $\mathrm{CO}_{2}$-eq/ $\mathrm{kWh}$ ), which is calculated by multiplying the quantity of the GHG by its global warming potential relative to $\mathrm{CO}_{2}$ [32].

The international standard (ISO 2016), which sets out the LCA framework, does not explicitly state which methodology should be used. Instead, it simply states that all emissions should be quantified by using one reference substance, which, as stated previously, is usually $\mathrm{CO}_{2}$ (ISO 2016). Examples of indicators for LCIAs relating to lifecycle $\mathrm{CO}_{2}$ emissions include IMPACT 2002+ and IPCC 2013 GWP100a [35]. 
As a result of the holistic nature of the climate change indicator and the widespread use of $\mathrm{CO}_{2}$ emissions per functional unit of energy ( $\mathrm{kWh}$ in this case), the main indicator of focus in Section 2.3 is global warming potential (GWP).

\subsubsection{Limitations of This LCA}

There are some limitations to the present LCA study. The data here is obtained from literature and EcoInvent 3.6. As research on PV systems is progressing quickly, more recent data is likely to be updated in the world. As such, there might be some discrepancies between the data used and real-world data. The second limitation is that the construction of the recycling facilities is not considered in this study. Therefore, the impacts observed from the LGRF and FRELP processes are likely to be lower than actual real-life impacts. However, this was not considered in most previous studies, so this study is comparable to other studies in literature in that sense. There could also possibly be more advanced technological developments in current years that could result in more efficient PV panels $\mathrm{f}$ vor better recycling processes. These developments have not been considered in this LCA. Finally, only multi-silicon panels are considered in this study as they are most widely used.

\section{Results}

\subsection{Midpoint Impact Assessment}

As the PV system consists of different subcomponents, it is necessary to investigate each component's proportions of environmental impact. For the landfill scenario, the impact of each sub-assembly component (panel, inverter, mounting system, electrical installation) was considered. For the LGRF and FRELP scenarios, the impact of transport to the recycling facility as well as the recycling impact were also considered along with the four sub-assemblies.

For the landfill scenario, for 15 of the impact assessment categories, the panel had the largest impact, as shown in Figure 2A. For instance, in the 'climate change' (GWP100) impact category, the panel contributed to $75 \%$ of the impact, followed by $12 \%$ for the mounting system, $9 \%$ for the inverter, and $8 \%$ for the electrical installation. This is consistent with a previous LCA study by Rashedi et al. [36] on different PV panels.

The panel did not have the largest impact in the 'freshwater ecotoxicity', 'marine ecotoxicity', and 'metal depletion' categories. The electrical installation system had the largest contribution of $58 \%$ for the' freshwater ecotoxicity', followed by the inverter at $25 \%$. The panel only contributed about $14 \%$ to this impact category. Electrical installation also had the largest contribution to the 'marine ecotoxicity' impact at 57\%.

For the LGRF scenario, some of the impacts are offset by the recycling process for each impact category, as shown in Figure 2B. The largest offset was in 'metal depletion', where the LGRF process reduced the impact by $16.7 \%$. This is because recycling reduced the resources used. The second-largest decrease in impact was for 'agricultural land occupation', where the impact was offset by $12.4 \%$ by the recycling process.

These offsets were even larger for the FRELP recycling process, as shown in Figure 2C. The largest decrease in environmental impact was in the 'urban land occupation' category, where the impact was offset by $34 \%$ by the recycling process. This was followed by the 'agricultural land occupation' and 'climate change' categories, where the FRELP process reduced the impact by $23 \%$ each. Interestingly, for both the LGRF and FRELP recycling processes, the transport to the recycling facility did not contribute much to the environmental impacts. 

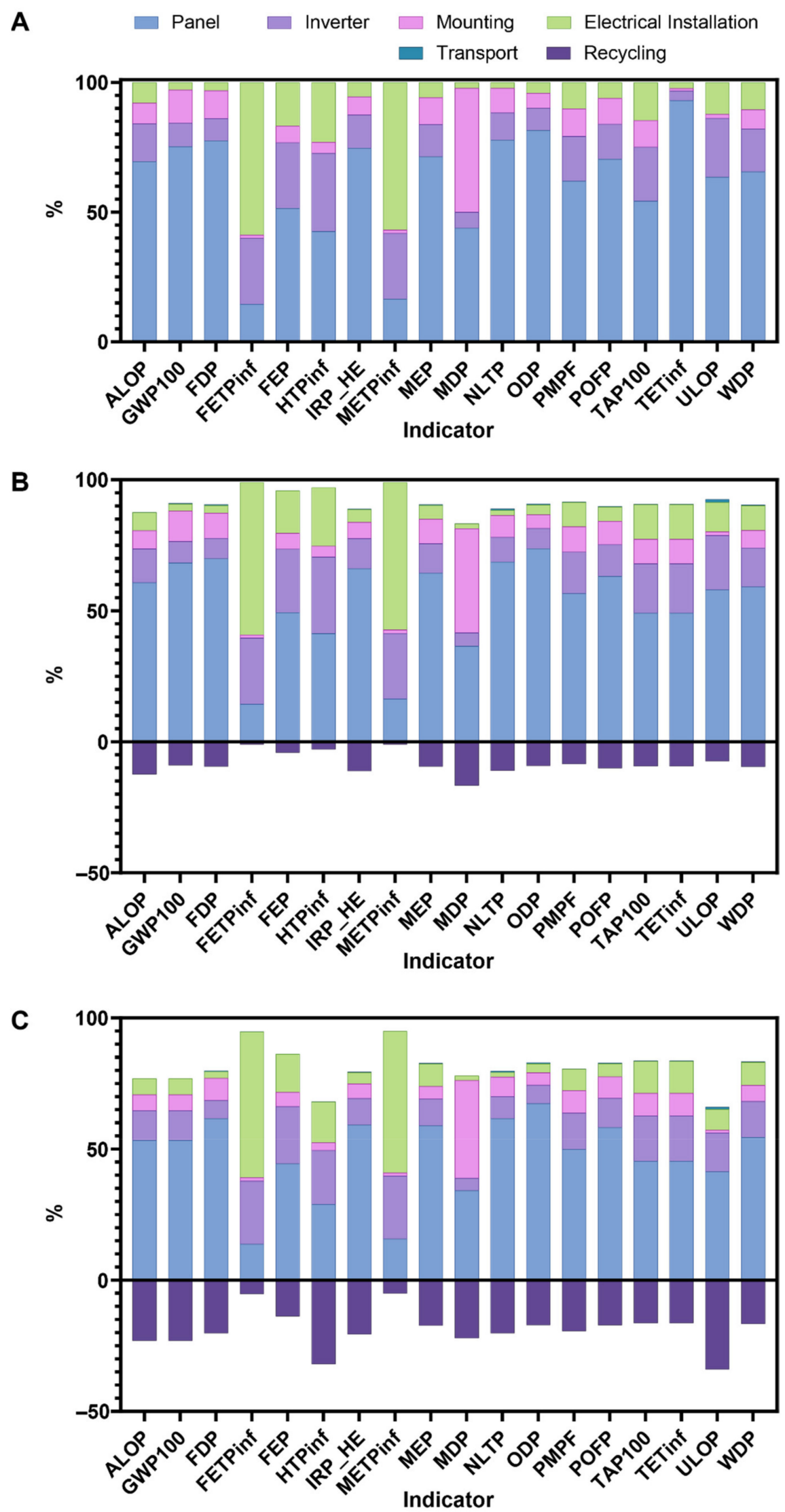

Figure 2. Results of ReCiPe Mid-point LCA. The contribution of each of the four major sub-assemblies to each impact category is shown. (A). Landfill scenario. (B). LGRF scenario. (C). FRELP scenario. 


\subsection{Endpoint Impact Assessment}

The endpoint impact indicators are an aggregation of the midpoint impacts. There are three endpoint indicators: human health, ecosystems, and resources. The scores obtained from these three impact categories are added to give a single final score (Figure 3).

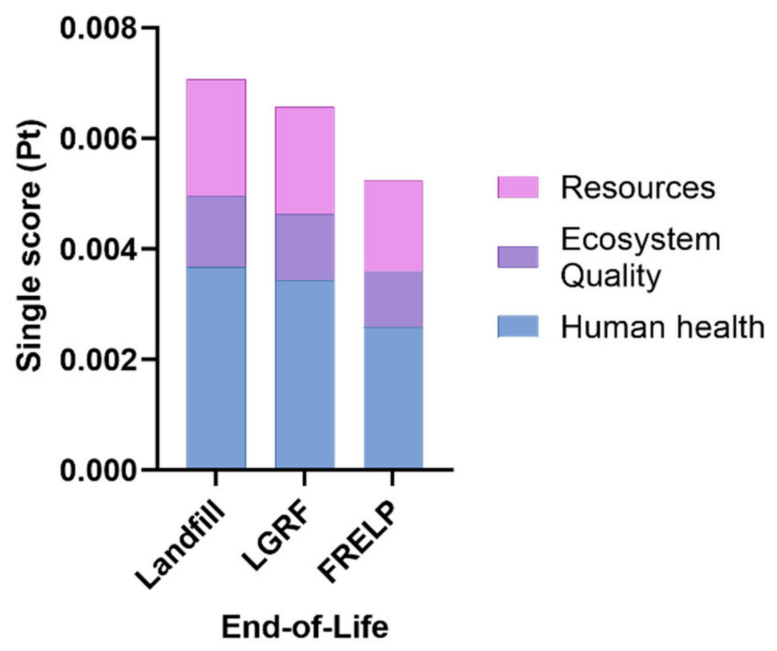

Figure 3. ReCiPe endpoint single score results for the three different EoL scenarios tested.

For the landfill scenario, the final single score was 0.00706 . For the recycling scenarios, a final score of 0.00657 and 0.00523 were obtained for the LGRF and FRELP scenarios, respectively, representing a $7 \%$ and $26 \%$ decrease, respectively. One point $(1 \mathrm{Pt})$ signifies the impact by an average citizen over one year. These results suggest that the LGRF and FRELP recycling processes have lower overall environmental impacts compared to the landfill scenario.

\subsection{Climate Change Impact}

Next, the climate change impact of the different EoL scenarios were evaluated, as shown in Figure 4. The amount of $\mathrm{CO}_{2}$ produced in the different scenarios were evaluated. Similar to the endpoint results, the LGRF and FRELP scenarios performed better than the landfill scenario. The $\mathrm{CO}_{2}$ emission to air for the landfill, LGRF, and FRELP scenarios were $0.059,0.054$, and $0.046 \mathrm{~kg}$ per $\mathrm{kWh}$, respectively.

\subsection{Increasing the Lifespan of Solar PV Systmes}

We also conducted an LCA for different lifespans of the PV system. In the base landfill scenario, the PV system had a lifetime of 30 years. We considered two additional landfill scenarios: landfill with PV system after a lifetime of 50 years and landfill with PV system after a hypothetical lifetime of 100 years. These new scenarios were added to investigate the effect of increasing the durability of the PV system components on lowering the impact assessment compared to the recycling scenarios.

The endpoint impact assessment of the three different lifespans tested gave scores of $0.00706,0.00424$, and 0.00212 for a PV system with a lifespan of 30, 50, and 100 years, respectively (Figure 5). The climate change indicator (GWP100) was also compared for the three different lifespans (Figure 6). The emissions of $\mathrm{CO}_{2}$ were $0.059,0.035$, and 0.018 for the 30,50 , and 100 years scenarios, respectively. 


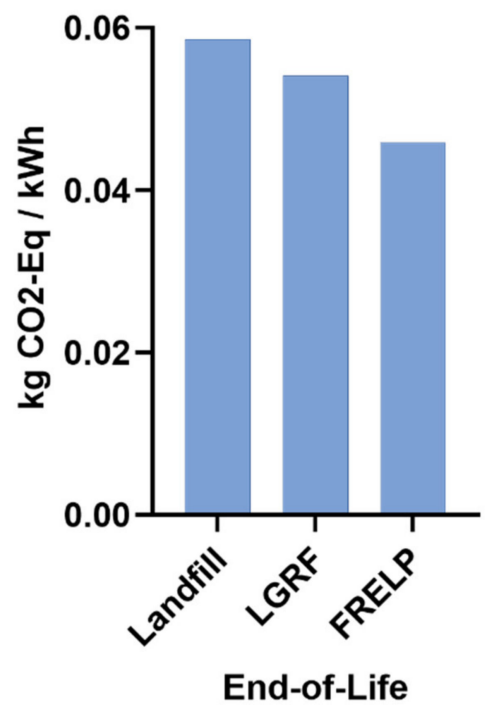

Figure 4. Climate change (GWP100) impact indicator. The amount of $\mathrm{CO}_{2}$ emitted by the different scenarios is shown here.

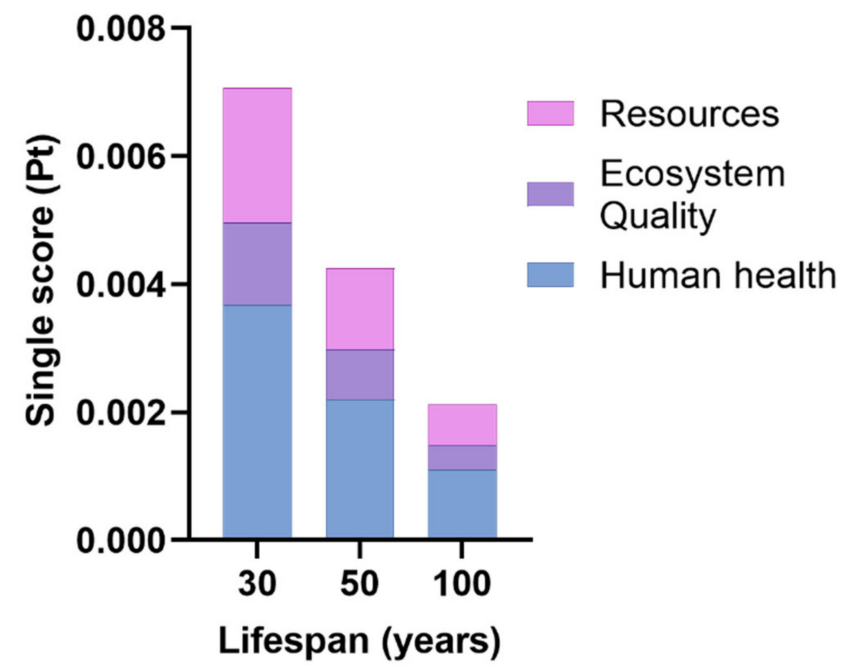

Figure 5. Endpoint scores for the landfill scenarios. Different lifespans of the PV system were compared.

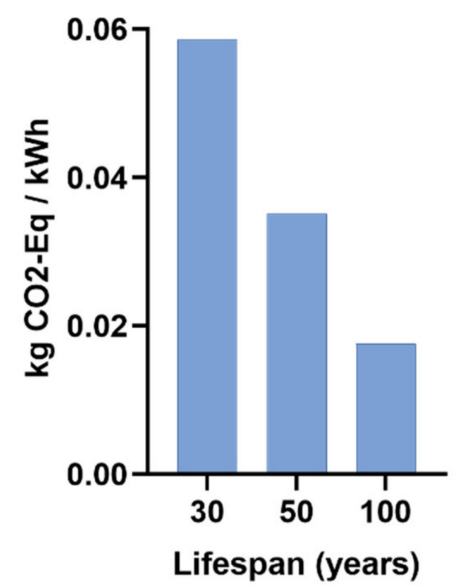

Figure 6. Climate change (GWP) indicator for landfill scenario with different lifetimes of PV system. 


\section{Discussion}

Our LCA results for the different EoL methods showed that recycling resulted in impact offsets, with greater offsets observed for the FRELP process compared to the LGRF process. However, these offsets were not huge. From our endpoint impact assessments, we found $7 \%$ and $26 \%$ decreases in the impact scores for LGRF and FRELP, respectively, as compared to the landfill scenario. Similarly, for the climate change potential, decreases of $8 \%$ and $22 \%$ in $\mathrm{CO}_{2}$ emission were obtained with LGRF and FRELP, respectively.

These impact offsets are now large. Furthermore, the construction of the recycling plants was not considered in this study. It is reasonable to expect that if the construction of the recycling plants were to be included, the emissions from the recycling process would be higher than what was found in the present LCA study.

As the recycling scenarios provided some but not a huge reduction in environmental impacts, an alternative strategy was also simulated for the landfill scenario whereby the lifespan of the panel is increased from 30 years to 50 and 100 years. Here, larger impact offsets were observed, with a $70 \%$ reduction in $\mathrm{CO}_{2}$ emission for 100 years compared to 30 years.

These results suggest that making more durable PV panels, mounting systems, inverters, and electrical components that are likely to last 50 years or more is a more viable option for reducing environmental impacts than recycling the panels. This is not surprising, as the recycling processes were limited to the recycling of the panels only. The recycling of the mounting system, the electrical installation components, and the inverter was not considered here. These were disposed into the landfill.

The result calls for a circular design of PV systems. This circular design should focus both on the design of the product and the process. The product design focus should be primarily on the PV panel design as it has the largest environmental impacts, as was shown in Figure 2.

An approach to achieving a circular design of the PV panels is standardization, which means a consistent technique of manufacturing and assembling the panels across the industry. This would not only simplify the design process, but it would also standardize the disassembly and recycling procedure, thereby reducing the need for multiple recycling facilities employing different technologies to be built. Currently, the lack of standardization across the industry makes it difficult for recycling plants to manage different panel types [37]. Therefore, a circular design approach that is focused on EoL could become an industry standard requirement, along with a product stewardship scheme where PV panel manufacturers take ownership of the panels throughout their lifetime. This circular economy business flip will ensure that manufacturers pay good attention to the design of their panels.

Another approach is to design the PV panels targeting longevity, that is, to only manufacture designs that are more efficient and more durable, such that they would have a longer lifespan. Currently, the EoL of panels is taken to be when the efficiency of the panes drops below $80 \%$. The efficiency drops by a median of $0.5 \%$ annually due to the degradation of the panel [38]. Chowdhury et al. [10] suggested that the main causes of PV panel failure are poor design and defects from manufacturing, damage to electrical equipment, light erosion, degradation of anti-reflective coating layer of ethylene-vinyl acetate (EVA) on glass and environmental contributions to degradation, and contact defects in junction boxed. Therefore, research on extending the lifetime of solar panels should focus on improving these areas.

Miller and Krishnaswami [39] suggest three methods to extend PV panel lifespan and reduce systems levelized costs: (i) to optimize the novel circuit design, which reduces the number of components within the system, contributing to less maintenance and great improvements in packing efficiency; (ii) the incorporation of a modular inverter design which allows for easy component replacement, enhancing PV system reliability; and (iii) the use of wide-bandgap semiconductor switches which can operate at greater temperatures with reduced power failure. 
When designing PV systems, material indicators such as the material circularity index (MCI) and material reutilization score (MRS) should be taken into consideration [40], and possibly made into standard requirements for manufacturers to report on. The MCI provides an overview of how much the PV system has transitioned from 'linear' to 'circular' [41]. The MRS indicates the recyclability potential of the system, considering both the possible and actual materials which are recycled.

\section{Conclusions}

This study presented an LCA of EoL (EoL) PV systems (for $1 \mathrm{kWh}$ electricity generation) in Australia. Three different EoL scenarios were considered: (i) disposal to landfill, (ii) recycling by laminated glass recycling facility (LGRF), and (iii) recycling by Full Recycling EoL Procedure (FRELP) for a 30-year PV system lifespan. Recycling technologies such as LGRF and FRELP were shown to reduce the overall impact score of the cradle-to-grave PV system from 0.00706 to 0.00657 (7\% decrease) and 0.00523 (26\% decrease), respectively, as measured using the ReCiPe endpoint single score. The $\mathrm{CO}_{2}$ emissions to air was also reduced from $0.059 \mathrm{~kg} \mathrm{CO}_{2}$ per $\mathrm{kWh}$ (landfill scenario, i.e., without recycling) to 0.054 and $0.046 \mathrm{~kg} \mathrm{CO}_{2}$ per $\mathrm{kWh}$ for the LGRF and FRELP scenarios, respectively.

The effect of increasing the lifespan of the PV system from 30 years to 50 and 100 years was also studied. The ReCiPe endpoint single score impacts for 30, 50, and 100 year lifespans were $0.00706,0.00424$ (40\% decrease), and 0.00212 (70\% decrease), respectively. Similarly, $\mathrm{CO}_{2}$ emissions were calculated at $0.059,0.035$, and $0.018 \mathrm{~kg} \mathrm{CO}$ per $\mathrm{kWh}$ for the 30,50 , and 100 years scenarios, respectively.

Our results show that recycling reduces the environmental impact of the EoL of PV system. However, the construction of the recycling plants was not considered in this study due to data limitations and is likely to increase the environmental impact of the recycling processes when accounted for. Increasing the lifespan of the PV system also reduces the environmental impacts. Our findings also showed that the PV panel has the greatest environmental impact compared to other components of the system (mounting system, the inverter, and the electrical installation). With rapid advances in the PV industry, there could possibly be more advanced technological developments in the coming years that could result in more efficient PV panels or better recycling processes. However, these developments have not been considered in this LCA.

Overall, our work shows that there is an imperative for the circular design of PV systems, which result in increased longevity.

Author Contributions: Conceptualization, A.A. and J.K.D.S.; methodology, J.K.D.S. and G.M. software, J.K.D.S.; formal analysis, J.K.D.S. and A.A.; resources, A.A.; writing—original draft preparation, J.K.D.S., G.M., and J.B.; writing-review and editing, A.A., G.P.R., and B.S.; visualization, J.K.D.S.; supervision, A.A.; project administration, A.A. All authors have read and agreed to the published version of the manuscript.

Funding: This research received no external funding.

Institutional Review Board Statement: Not applicable.

Informed Consent Statement: Not applicable.

Data Availability Statement: Not applicable.

Conflicts of Interest: The authors declare no conflict of interest.

\section{References}

1. IRENA. End-of-Life Management: Solar Photovoltaic Panels; International Renewable Energy Agency: Abu Dhabi, United Arab Emirates; International Energy Agency Photovoltaic Power Systems Programme: Paris, France, 2016.

2. Zou, H.; Du, H.; Brown, M.A.; Mao, G. Large-scale PV power generation in China: A grid parity and techno-economic analysis. Energy 2017, 134, 256-268. [CrossRef]

3. Bazilian, M.; Onyeji, I.; Liebreich, M.; MacGill, I.; Chase, J.; Shah, J.; Gielen, D.; Arent, D.; Landfear, D.; Zhengrong, S. Reconsidering the economics of photovoltaic power. Renew. Energy 2013, 53, 329-338. [CrossRef] 
4. Louwen, A.; Van Sark, W.; Schropp, R.; Faaij, A. A cost roadmap for silicon heterojunction solar cells. Solar Energy Mater. Solar Cells 2016, 147, 295-314. [CrossRef]

5. Louwen, A.; Van Sark, W.; Schropp, R.; Turkenburg, W.; Faaij, A. Life-cycle greenhouse gas emissions and energy payback time of current and prospective silicon heterojunction solar cell designs. Prog. Photovolt. Res. Appl. 2015, 23, 1406-1428. [CrossRef]

6. Hsu, D.D.; O’Donoughue, P.; Fthenakis, V.; Heath, G.A.; Kim, H.C.; Sawyer, P.; Choi, J.K.; Turney, D.E. Life cycle greenhouse gas emissions of crystalline silicon photovoltaic electricity generation: Systematic review and harmonization. J. Ind. Ecol. 2012, 16, S122-S135. [CrossRef]

7. Zhang, L.; Ciftja, A. Recycling of solar cell silicon scraps through filtration, Part I: Experimental investigation. Solar Energy Mater. Solar Cells 2008, 92, 1450-1461. [CrossRef]

8. Hammoumi, A.E.; Motahhir, S.; Ghzizal, A.E.; Chalh, A.; Derouich, A. A simple and low-cost active dual-axis solar tracker. Energy Sci. Eng. 2018, 6, 607-620. [CrossRef]

9. Chalh, A.; Motahhir, S.; El Hammoumi, A.; El Ghzizal, A.; Derouich, A. Study of a Low-Cost PV Emulator for Testing MPPT Algorithm Under Fast Irradiation and Temperature Change. Technol. Econ. Smart Grids Sustain. Energy 2018, 3, 11. [CrossRef]

10. Chowdhury, M.S.; Rahman, K.S.; Chowdhury, T.; Nuthammachot, N.; Techato, K.; Akhtaruzzaman, M.; Tiong, S.K.; Sopian, K.; Amin, N. An overview of solar photovoltaic panels' end-of-life material recycling. Energy Strategy Rev. 2020, $27,100431$. [CrossRef]

11. Australian Energy Council. Solar Report, in Quarter 1, 2020; Australian Energy Council: Melbourne, VIC, Australia, 2020.

12. Pukšec, T.; Foley, A.; Markovska, N.; Duić, N. Life cycle to Pinch Analysis and $100 \%$ renewable energy systems in a circular economy at sustainable development of energy, Water and Environment Systems 2017. Renew. Sustain. Energy Rev. 2019, 108, 572-577. [CrossRef]

13. IEA. Renewables 2018: Analysis and Forecasts to 2023; IEA: Paris, France, 2018.

14. Mahmoudi, S.; Huda, N.; Behnia, M. Environmental impacts and economic feasibility of end of life photovoltaic panels in Australia: A comprehensive assessment. J. Clean. Prod. 2020, 260, 120996. [CrossRef]

15. Giacchetta, G.; Leporini, M.; Marchetti, B. Evaluation of the environmental benefits of new high value process for the management of the end of life of thin film photovoltaic modules. J. Clean. Prod. 2013, 51, 214-224. [CrossRef]

16. Dwivedy, M.; Suchde, P.; Mittal, R. Modeling and assessment of e-waste take-back strategies in India. Resour. Conserv. Recycl. 2015, 96, 11-18. [CrossRef]

17. Kusch, S.; Alsheyab, M.A. Waste electrical and electronic equipment (WEEE): A closer look at photovoltaic panels. In Proceedings of the 17th International Multidisciplinary Scientific Geoconference SGEM, Vienna, Austria, 27-29 November 2017; pp. 317-324.

18. Cucchiella, F.; D'Adamo, I.; Koh, S.L.; Rosa, P. Recycling of WEEEs: An economic assessment of present and future e-waste streams. Renew. Sustain. Energy Rev. 2015, 51, 263-272. [CrossRef]

19. Ellen-Mcarthur-Foundation. The Circular Economy in Detail; Ellen-Mcarthur-Foundation: Cowes, UK, 2017.

20. Fraunhofer-ISE. Photovoltaics Report; Fraunhofer Institute for Solar Energy Systems: Freiburg, Germany, 2020.

21. Department of Industry, Science, Energy and Resources. Australian Energy Update 2020; Australian Energy Statistics: Canberra, ACT, Australia, 2020.

22. Latunussa, C.E.; Ardente, F.; Blengini, G.A.; Mancini, L. Life Cycle Assessment of an innovative recycling process for crystalline silicon photovoltaic panels. Solar Energy Mater. Solar Cells 2016, 156, 101-111. [CrossRef]

23. Celik, I. Eco-Design of Emerging Photovoltaic (PV) Cells; University of Toledo: Toledo, OH, USA, 2018.

24. The European Parliament and The Council Of The European Union, Directive 2012/19/Eu Of The European Parliament and of The Council of 4 July 2012 on waste electrical and electronic equipment (WEEE). Off. J. Eur. Union 2012, 197, 38-71.

25. European Commision. Mandate for the Development of (a) Standards for the Treatment of Waste Electrical and Electronic Equipment (WEEE); European Commision: Brussels, Belgium, 2013.

26. Seyring, N.; Kling, M.; Weissenbacher, J.; Hestin, M.; Lecerf, L.; Magalini, F.; Khetriwal, D.S.; Kuehr, R. Study on WEEE Recovery Targets, Preparation for Re-Use Targets and on the Method for Calculation of the Recovery Targets; EU Commission: Brussels, Belgium, 2015.

27. Faircloth, C.C.; Wagner, K.H.; Woodward, K.E.; Rakkwamsuk, P.; Gheewala, S.H. The environmental and economic impacts of photovoltaic waste management in Thailand. Resour. Conserv. Recycl. 2019, 143, 260-272. [CrossRef]

28. ISO. Environmental Management: Life Cycle Assessment; Principles and Framework; ISO International Organization for Standardization: Geneva, Switzerland, 2006; Volume 14044.

29. ISO. Environmental Management: Life Cycle Assessment; Requirements and Guidelines; ISO International Organization for Standardization: Geneva, Switzerland, 2006.

30. International Energy Agency Photovoltaic Power Systems Program (IEA PVPS). End-of-Life Management of Photovoltaic Panels: Trends in PV Module Recycling Technologies. IEA PVPS Task 12, Publication No. 1. 2018. Available online: http:/ / iea-pvps.org/ index.php?id=459 (accessed on 26 November 2020).

31. Huang, W.-H.; Shin, W.J.; Wang, L.; Sun, W.-C.; Tao, M. Strategy and technology to recycle wafer-silicon solar modules. Solar Energy 2017, 144, 22-31. [CrossRef]

32. Huijbregts, M.A.; Steinmann, Z.J.; Elshout, P.M.; Stam, G.; Verones, F.; Vieira, M.; Zijp, M.; Hollander, A.; van Zelm, R. ReCiPe2016: A harmonised life cycle impact assessment method at midpoint and endpoint level. Int. J. Life Cycle Assess. 2017, 22, 138-147. [CrossRef] 
33. Goedkoop, M.; Heijungs, R.; Huijbregts, M.; De Schryver, A.; Struijs, J.; Van Zelm, R. ReCiPe 2008: A Life Cycle Impact Assessment Method Which Comprises Harmonised Category Indicators at the Midpoint and the Endpoint Level, 1st ed.; Leiden University: Leiden, The Netherlands, 2009; pp. 1-126.

34. Finnveden, G.; Hauschild, M.Z.; Ekvall, T.; Guinée, J.; Heijungs, R.; Hellweg, S.; Koehler, A.; Pennington, D.; Suh, S. Recent developments in life cycle assessment. J. Environ. Manag. 2009, 91, 1-21. [CrossRef]

35. Menoufi, K.A.I. Life Cycle Analysis and Life Cyle Impact Assessment Methodologies: A State of the Art; Universitat de Lleida: Lleida, Spain, 2011.

36. Rashedi, A.; Khanam, T. Life cycle assessment of most widely adopted solar photovoltaic energy technologies by mid-point and end-point indicators of ReCiPe method. Environ. Sci. Pollut. Res. 2020, 27, 29075-29090. [CrossRef] [PubMed]

37. Sica, D.; Malandrino, O.; Supino, S.; Testa, M.; Lucchetti, M.C. Management of end-of-life photovoltaic panels as a step towards a circular economy. Renew. Sustain. Energy Rev. 2018, 82, 2934-2945. [CrossRef]

38. Jordan, D.; Kurtz, S. Photovoltaic Degradation Rates-An Analytical Review: Progress in Photovoltaics: Research and Applications; National Renewable Energy Laboratory, U.S. Department of Energy: Golden, CO, USA, 2012; pp. 1-32.

39. Miller, J.; Krishnaswami, H. Extending Solar Energy System Lifetime with Power Electronics. Available online: https://www. energy.gov / eere/solar/articles/extending-solar-energy-system-lifetime-power-electronics (accessed on 26 November 2020).

40. Linder, M.; Sarasini, S.; van Loon, P. A metric for quantifying product-level circularity. J. Ind. Ecol. 2017, 21, 545-558. [CrossRef]

41. Ellen MacArthur Foundation; Granta Design. Circularity Indicators: An Approach to Measuring Circularity; Ellen Macarthur Foundation: Cowes, UK, 2015. 